\title{
The Model and Parameters Based on the Operation Mode of a 500kV Multi-terminal Flexible DC Power Grid
}

\author{
LI Zhen-dong, TANG Yu-dong, ZHAO Zhe-yuan, WU Xiao-bo, FAN Cai-jie, LI Li, HAN \\ Yan \\ ${ }^{1}$ State Grid Jibei Electricity Power Maintenance Company, Beijing, China \\ ${ }^{2}$ State Grid Jibei Electric Power Company, Beijing, China \\ vibrateli@163.com
}

Keywords: Multi-terminal Flexible DC System, MMC, Parameter Configuration, Control System.

\begin{abstract}
The operating conditions of 500kV Zhangjiakou-Beijing Demonstration Project at all operation modes were studied regarding a multi-terminal flexible DC system with DC switches and a true bipolar wiring method. Based on the actual AC-DC hybrid method, this paper concluded 34 kinds of $\mathrm{N}-1$ operation modes for keeping the system stable, simulated the multi-level converter valve (MMC) bank by using RTDS small-step elements, adopted an ideal voltage balancing method for the treatment of sub-units and established a MCC system simulating structure in compliance with the site. The operation modes of the system were simulated by selecting the parameters which are consistent with the line, using such parameters as the actual configurations and parameters of key elements such as the converter transformer, filter, bridge arm reactor, converter, etc. adopted in the project, and establishing a flexible DC control system with a layered structure. According to the result of the simulation, the corresponding modes of the system were provided and references were given for the feasibility study and implementation of the project.
\end{abstract}

\section{Introduction}

The flexible DC power transmission technology has crucial technical advantages in large-scale new energy development and can meet reliable delivery and consumption of green energy in Zhangjiakou such as wind power, solar energy, etc. In order to provide support for 2022 low-carbon green Winter Olympics, it is planned to implement a $\pm 500 \mathrm{kV}$ Flexible DC Power Grid Demonstration Project with the highest voltage class in the world by that time in Zhangjiakou Stateclass Comprehensive New Energy Demonstration Zone and the special areas for the Winter Olympics.

The Project will be equipped with key equipment such as DC circuit breakers, DC line fast protective devices, large-capacity converter valves, etc.; a DC coordination control system which integrates multiple kinds of energy sources will be constructed; and a flexible four-terminal loop 
DC power grid will be set up to delivery multiple energy generated from large-scale wind power, solar energy, pumped storage power, etc ${ }^{[1-5]}$.

The Demonstration Project will use a loop power grid which has the following advantages: (a) highly reliable, able to realize the transfer of tide after failure; (b) flexible, able to realize flexible interaction among multiple energy resources and improve utilization efficiency; (c) good expandability, easy to expand new points at transmission and receiving ends. See Figure 1 for the AC-DC hybrid network of Phase I of the Demonstration Project ${ }^{[6-9]}$.

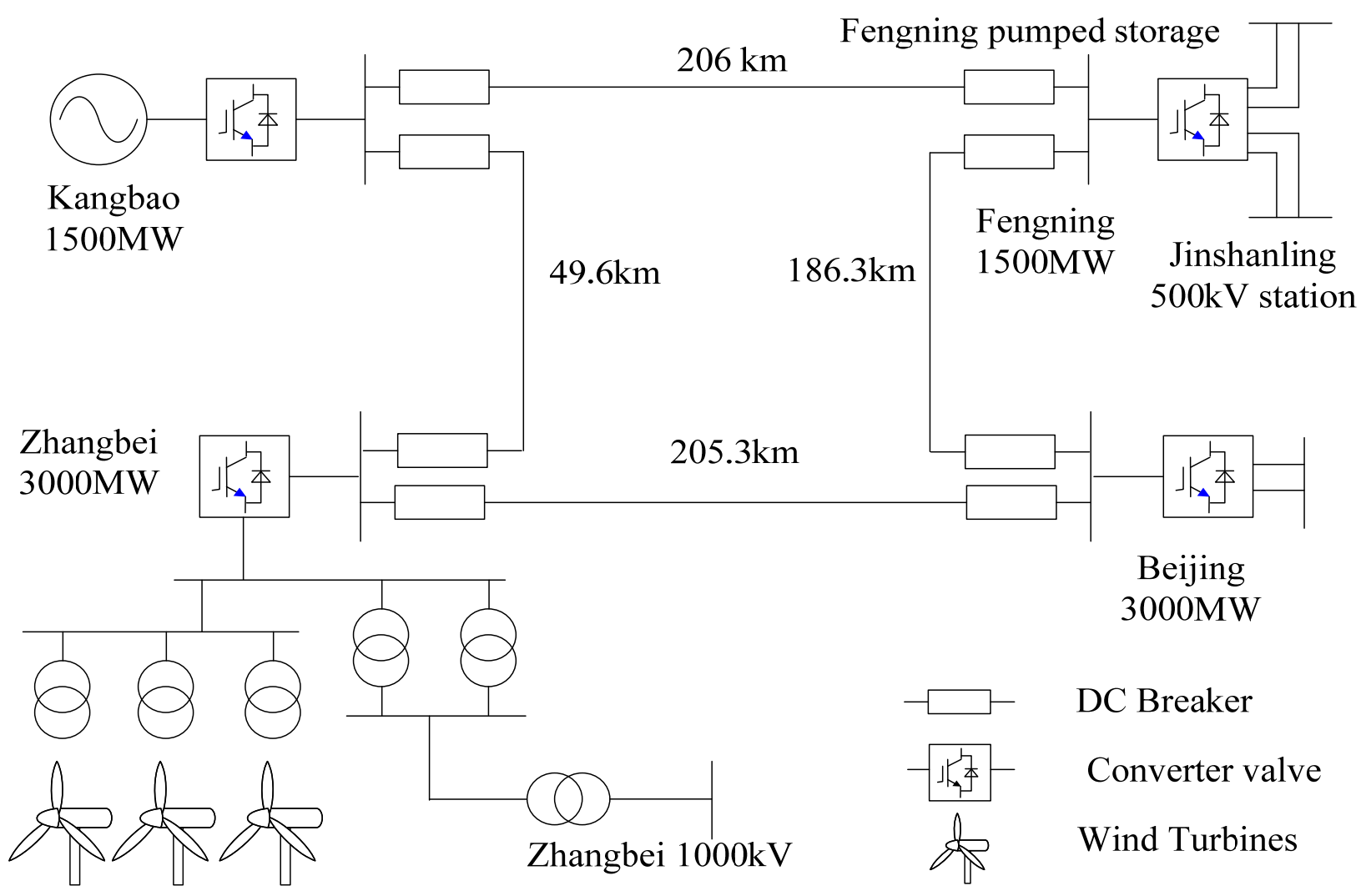

Figure 1 Initial AC-DC hybrid Connection Diagram

\subsection{The Structure of the Power Grid of the Demonstration Project}

Three $\pm 500 \mathrm{kV}$ sending end flexible converter stations will be built in Zhangbei, Kangbao and Fengning respectively. The capacity in Zhangbei will be $3000 \mathrm{MW}$, and the ones in Kangbao and Fengning, $1500 \mathrm{MW}$. A $\pm 500 \mathrm{kV}$ receiving end flexible converter station will be built with a capacity of $3000 \mathrm{MW}$. The transmission line of the Project will pass through Northern Hebei and Beijing and is $654.2 \mathrm{~km}$ long. Considering the large capacity and high voltage class of the Demonstration Project, a flexible DC power transmission system with overhead lines will be adopted after demonstration, and a bipolar wiring plan will be used as the main wiring method in order to improve reliability.

\subsection{The Operation Modes of the Demonstration Project}

The converter station can be divided into three areas according to the structure of the converter station, namely a converter area, a DC busbar area and a DC line area. The monopole (bipolar) failures in any area may result in decommission of the monopole (bipolar). In order to ensure power supply reliability, the Demonstration Project N-1 totally has 34 kinds of operation modes, as shown in Table 1. 
Table 2 List of Operation Modes of Demonstration Project N-1

\begin{tabular}{|c|c|c|c|c|c|}
\hline No. & Mode & No. & Mode & No. & Mode \\
\hline 1 & Normal operation mode & 13 & Fengning bipolar interlock & 25 & $\begin{array}{l}\text { Fengning- Beijing } \\
\text { channel cutoff }\end{array}$ \\
\hline 2 & $\begin{array}{l}\text { Zhangbei positive pole } \\
\text { interlock }\end{array}$ & 14 & $\begin{array}{l}\text { Zhangbei- Beijing positive } \\
\text { line trip }\end{array}$ & 26 & $\begin{array}{l}\text { Beijing outlet double } \\
\text { channel cutoff }\end{array}$ \\
\hline 3 & $\begin{array}{c}\text { Zhangbei negative pole } \\
\text { interlock }\end{array}$ & 15 & $\begin{array}{l}\text { Zhangbei- Beijing negative } \\
\text { line trip }\end{array}$ & 27 & $\begin{array}{c}\text { Zhangbei DC positive } \\
\text { busbar failure }\end{array}$ \\
\hline 4 & $\begin{array}{l}\text { Beijing positive pole } \\
\text { interlock }\end{array}$ & 16 & $\begin{array}{l}\text { Kangbao- Zhangbei positive } \\
\text { line trip }\end{array}$ & 28 & $\begin{array}{c}\text { Zhangbei DC negative } \\
\text { busbar failure }\end{array}$ \\
\hline 5 & $\begin{array}{l}\text { Zhangbei negative pole } \\
\text { interlock }\end{array}$ & 17 & $\begin{array}{l}\text { Kangbao- Zhangbei negative } \\
\text { line trip }\end{array}$ & 29 & $\begin{array}{c}\text { Kangbao DC positive } \\
\text { busbar failure }\end{array}$ \\
\hline 6 & $\begin{array}{l}\text { Kangbao positive pole } \\
\text { interlock }\end{array}$ & 18 & $\begin{array}{l}\text { Kangbao- Fengning positive } \\
\text { line trip }\end{array}$ & 30 & $\begin{array}{c}\text { Kangbao DC negative } \\
\text { busbar failure }\end{array}$ \\
\hline 7 & $\begin{array}{l}\text { Kangbao negative pole } \\
\text { interlock }\end{array}$ & 19 & $\begin{array}{l}\text { Kangbao- Fengning negative } \\
\text { line trip }\end{array}$ & 31 & $\begin{array}{c}\text { Fengning DC positive } \\
\text { busbar failure }\end{array}$ \\
\hline 8 & $\begin{array}{l}\text { Fengning positive pole } \\
\text { interlock }\end{array}$ & 20 & $\begin{array}{l}\text { Fengning- Beijing positive } \\
\text { line trip }\end{array}$ & 32 & $\begin{array}{c}\text { Fengning DC negative } \\
\text { busbar failure }\end{array}$ \\
\hline 9 & $\begin{array}{c}\text { Fengning negative pole } \\
\text { interlock }\end{array}$ & 21 & $\begin{array}{l}\text { Fengning- Beijing negative } \\
\text { line trip }\end{array}$ & 33 & $\begin{array}{l}\text { Beijing DC positive } \\
\text { busbar failure }\end{array}$ \\
\hline 10 & $\begin{array}{c}\text { Zhangbei bipolar } \\
\text { interlock }\end{array}$ & 22 & $\begin{array}{l}\text { Zhangbei- Beijing channel } \\
\text { cutoff }\end{array}$ & 34 & $\begin{array}{l}\text { Beijing DC negative } \\
\text { busbar failure }\end{array}$ \\
\hline 11 & Beijing bipolar interlock & 23 & $\begin{array}{l}\text { Kangbao- Zhangbei channel } \\
\text { cutoff }\end{array}$ & & \\
\hline 12 & $\begin{array}{c}\text { Kangbao bipolar } \\
\text { interlock }\end{array}$ & 24 & $\begin{array}{l}\text { Kangbao- Fengning channel } \\
\text { cutoff }\end{array}$ & & \\
\hline
\end{tabular}

The positive (negative) pole interlock in Items 2-9 in Table 1 means that in the normal operation mode, the monopole of the converter station interlocks, but the DC busbar and all DC lines operate normally. The bipolar interlock in Items 10-13 means that in the normal operation mode, the double pole of the converter station interlocks (namely, there is no power exchange from AC system to DC system at the converter station at this time), but the DC busbar and all DC lines operate normally. The positive (negative) line trip in Items 14-21 means, in the normal operation mode, that the double pole of the converter station operates normally; that the DC positive (negative) line fails; that the DC circuit breaker trips and disconnects the line; and that the DC busbar operates normally. The channel cutoff in Items 22-25 means, in the normal operation mode, that the DC double pole line fails; that the DC circuit breaker disconnects the line; and that the DC busbar operates normally. The double channel cutoff in Item 26 in Table 1 considers that there is a line converged by Zhangbei- Beijing Line and Fengning- Beijing Line at the entrance of Beijing Station, which share the same tower. When the line fails, this will lead to failure of all of the lines connected with Beijing Station, and the double pole of the converter will no longer output active power. The failure of the DC busbar in Item 27-34 means, in the normal operation mode, that the positive (negative) busbar fails; that all DC positive (negative) lines connecting to each other trip; and that the positive (negative) pole of the converter will no longer output active power at the same time.

\section{Establishing a Simulation Model}

\subsection{Primary System Structure}

According to the main wiring diagram and operation mode, the AC network among Kangbao 
Converter Station, Zhangbei Converter Station and Beijing Converter Station is relatively close. Because Fengning Converter Station is far from the three converter stations, a model will be established for the AC system around Kangbao - Zhangbei-Beijing and from the AC system around Fengning separately. See Table 2 for the parameters of the line.

Table 2 Parameters of Demonstration Project Line

\begin{tabular}{|c|c|c|}
\hline Line(km/A) & Length & Rated current \\
\hline Kangbao Converter Station-Kangbao 500kV Station & 30 & 2500 \\
\hline Zhangbei Converter Station-Zhangbei ultra-high voltage (500kV side) & 10 & 2500 \\
\hline Fengning Converter Station-Jinshanling 500kV Transformer Substation & $2 \times 100$ & 2500 \\
\hline Beijing Converter Station-Changping 500kV Station & 49 & 2500 \\
\hline Kangbao 500kV Station-Zhangjiakou ultra-high voltage & 30 & 2500 \\
\hline Zhangjiakou ultra-high voltage-Zhangnan 500kV Station & 185 & 2500 \\
\hline Zhangnan 500kV Station-Changping 500kV Station & 103 & 2800 \\
\hline
\end{tabular}

RTDS simulates the MMC multiple-level converter valve bank by using small-step elements. The CHAIN5 and MMC5 models therein needs no FPGA cards. All sub-units inside MMC are treated by using an ideal voltage balancing method. The input signal for the CHAIN5 model is modulated wave, and the input signal for the MMC5 model is the number of NLM level. At present, NLM modulate and MMC5 model are used. Six MMC5 models are established into a three-phase half-bridge, and then the half-bridge is connected to a converter transformer and a DC line to obtain a monopole model.

Because the simulation duration of each small-step elements is more than $3 \mathrm{~ns}$, the simulation of all small-step elements in a small-step model should be completed in order in each large-step. Therefore, a small-step model includes at most 16 small-step elements. A monopole MMC structure totally includes totally 11 elements: six MMCs, three single-phase conversion transformers from large-step to small-step, one three-phase starting resistor and one DC line. A bipolar MMC structure includes totally 22 elements and cannot be built in a small-step model. Therefore, a monopole structure must be used. See Figure 2 for the structure of a single converter station.

The blue box in Figure 2 is one small-step model, which needs to occupy a PB5/GPC card exclusively for simulation. In the $\mathrm{AC}$ system, three single-phase transformers are connected with small-step MMC elements; the AC output from MMC elements is connected to large-step simulation via an interface line and then to the DC network via a large-step line.

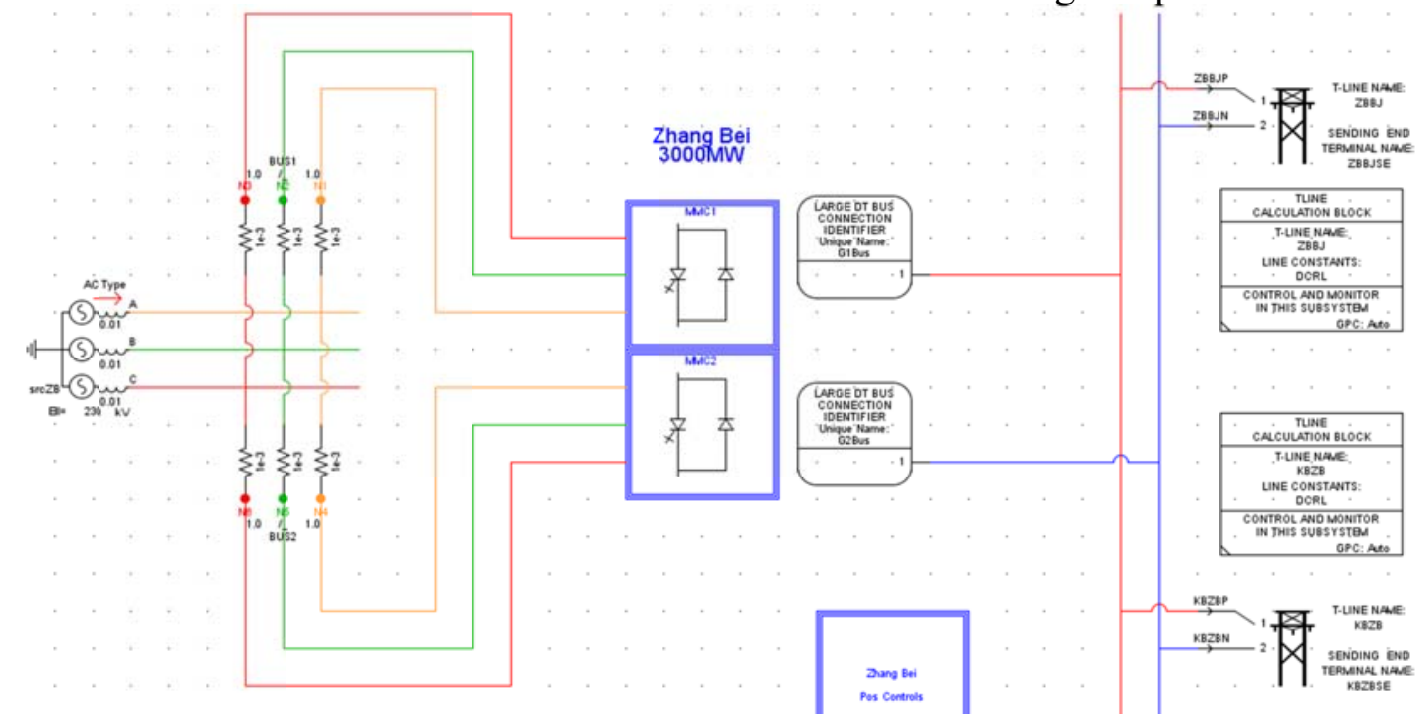

Figure 2 MCC System Simulation Structure 
Each single-end converter station needs two small-step models for simulating positive and negative converter units (a combination of converter transformer, start resistance and converter) respectively. Therefore, the single-end converter station needs totally four PB5/GPC cards: two PB5/GPC cards, one PB5/GPC card for network calculation and one PB5/GPC for control quantity calculation. At present, Rack8 cannot simulate the system because it has only three PB5 card, and other Racks are suitable for such simulation.

\subsection{Converter Valve System Parameters}

See Figure 3 for the basic structure of the flexible DC power transmission of multiple-level converter. The structure is similar to conventional DC structures and comprised of a converter transformer, a filter, bridge arm reactor, a converter and a DC line; however, the converter has a different structure.

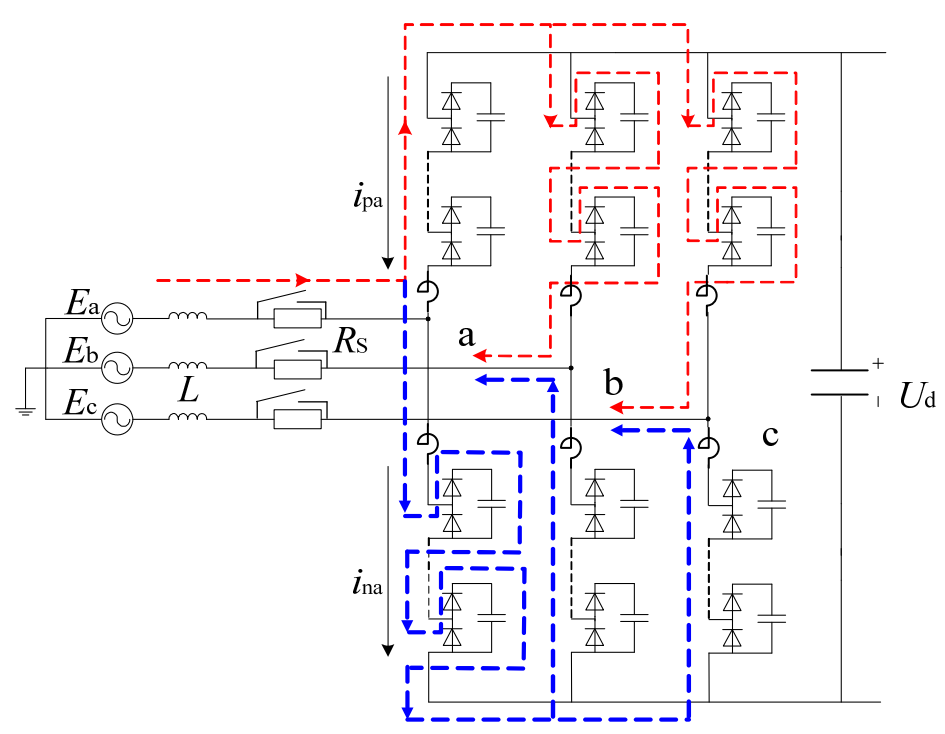

Figure 3 Structure of MMC Converter Valve

Each phase is comprised of multiple sub-modules. According to actual demonstration, each submodule has a half-H bridge structure. For the main parameters of primary equipment, see the parameters of the converter transformer in Table 3 and the parameters of the converter valve in Table 4.

\subsection{Control System Model}

The MMC flexible (modular multilevel) control system has the same structure with the VSC flexible (two-level/three-level) control system and can be divided into system-level control, converter-level control and trigger-level, as shown in Figure 4. 
Table 3 Parameters of Converter Transformer

\begin{tabular}{|c|c|c|c|c|}
\hline Three phase & Beijing & Zhangbao & Kangbao & Fengning \\
\hline Rated capacity of transformer & $2 \times 1700$ & $2 \times 1700$ & $2 \times 850$ & $2 \times 850$ \\
\hline $\begin{array}{l}\text { short-circuit impedance of } \\
\text { transformer }\end{array}$ & 0.15 & 0.15 & 0.15 & 0.15 \\
\hline $\begin{array}{l}\text { Rated voltage at the transformer } \\
\text { network side }\end{array}$ & 525 & 230 & 230 & 525 \\
\hline $\begin{array}{l}\text { Rated voltage at the transformer } \\
\text { valve side }\end{array}$ & 260.26 & 260.26 & 260.26 & 260.26 \\
\hline Transformer range & 0.0125 & 0.0125 & 0.0125 & 0.0125 \\
\hline Tap position range & $9-0$ & $10-0$ & $10-0$ & $10-0$ \\
\hline Connection group of transformer & \multicolumn{4}{|c|}{$\mathrm{Yn} / \triangle$} \\
\hline Single phase & Beijing & Zhangbao & Kangbao & Fengning \\
\hline Rated capacity of transformer & 566.67 & 566.67 & 283.33 & 283.33 \\
\hline $\begin{array}{c}\text { short-circuit impedance of } \\
\text { transformer }\end{array}$ & 0.15 & 0.15 & 0.15 & 0.15 \\
\hline $\begin{array}{l}\text { Rated voltage at the transformer } \\
\text { network side }\end{array}$ & 303.11 & 132.79 & 132.79 & 303.11 \\
\hline $\begin{array}{l}\text { Rated voltage at the transformer } \\
\text { valve side }\end{array}$ & 260.26 & 260.26 & 260.26 & 260.26 \\
\hline Transformer range & 0.0125 & 0.0125 & 0.0125 & 0.0125 \\
\hline Tap position range & $9-0$ & $10-0$ & $10-0$ & $10-0$ \\
\hline Connection group of transformer & \multicolumn{4}{|c|}{$\mathrm{Yn} / \triangle$} \\
\hline Starting resistance & 6 & 6 & 6 & 6 \\
\hline Extinction capacity (kA) & $0-1 \mathrm{e} 6$ & $0-1 \mathrm{e} 6$ & $0-1 \mathrm{e} 6$ & $0-1 \mathrm{e} 6$ \\
\hline
\end{tabular}

Table 4 Parameters of Converter Valve

\begin{tabular}{|c|c|c|c|c|}
\hline Name & Beijing & Zhangbao & Kangbao & Fengning \\
\hline Rated voltage & $\pm 500 \mathrm{kV}$ & $\pm 500 \mathrm{kV}$ & $\pm 500 \mathrm{kV}$ & $\pm 500 \mathrm{kV}$ \\
\hline Maximum DC power & 3000 & 3000 & 1500 & 1500 \\
\hline Capacitance value of sub-module & 15 & 15 & 10 & 10 \\
\hline $\begin{array}{l}\text { Working voltage of sub-module in the } \\
\text { steady state }\end{array}$ & 2.2936 & 2.2936 & 2.2936 & 2.2936 \\
\hline IGBT parameters & $4.5 \mathrm{kV} / 3 \mathrm{kA}$ & $4.5 \mathrm{kV} / 3 \mathrm{kA}$ & $4.5 \mathrm{kV} / 2 \mathrm{kA}$ & $4.5 \mathrm{kV} / 2 \mathrm{kA}$ \\
\hline The number of sub-modules/bridge arm & 240 & 240 & 240 & 240 \\
\hline $\begin{array}{c}\text { Maximum effective value of bridge arm } \\
\text { current (A) }\end{array}$ & 2100 & 2100 & 1050 & 1050 \\
\hline Maximum transient withstand current peak & $6 \mathrm{kA} / 6 \mathrm{~ms}$ & $6 \mathrm{kA} / 6 \mathrm{~ms}$ & $3 \mathrm{kA} / 6 \mathrm{~ms}$ & $3 \mathrm{kA} / 6 \mathrm{~ms}$ \\
\hline Failure withstand current peak & $20 \mathrm{kA} / 100 \mathrm{~ms}$ & $20 \mathrm{kA} / 100 \mathrm{~ms}$ & $12 \mathrm{kA} / 100 \mathrm{~ms}$ & $12 \mathrm{kA} / 100 \mathrm{~ms}$ \\
\hline Bridge arm reactance & 40 & 40 & 75 & 75 \\
\hline Capacitor discharge duration & $2-4000 \mathrm{~s}$ & $2-4000 \mathrm{~s}$ & $2-4000 \mathrm{~s}$ & $2-4000 \mathrm{~s}$ \\
\hline On-resistance of sub-module & $0.00033-0.01$ & $0.00033-0.01$ & $0.00033-0.01$ & $0.00033-0.01$ \\
\hline Off-resistance of sub-module & $1-5 e 4$ & $1-5 \mathrm{e} 4$ & $1-5 \mathrm{e} 4$ & $1-5 \mathrm{e} 4$ \\
\hline Snubber circuit Xc & $400-1 \mathrm{e} 4$ & $400-1 \mathrm{e} 4$ & $400-1 \mathrm{e} 4$ & $400-1 \mathrm{e} 4$ \\
\hline Time constant of snubber, us & $4-50$ & $4-50$ & $4-50$ & $4-50$ \\
\hline
\end{tabular}


The system-level control includes the start and stop of the converter station, the switching of converter station operating mode, the determination of total output power and other controls, which should be performed in combination with DC network analysis. The converter-level control receives operating mode and power/voltage instructions from the system-level control and transfers them into converter trigger instructions by control external and internal loops. The trigger-level control involves more fine controls of all sub-modules such as voltage balancing, ordering, start, stop, etc. According to three-level control classification and in combination with model establishing resources, the establishing of the flexible DC system can be divided into two directions for study: one direction is the system-level control and converter station control, and the other one is the trigger-level control. In the system-level control and converter station control, the MMC unit of an average voltage model can be adopted without using a GTFPGA card; in the trigger-level control, more considerations are given to the balancing algorithm of the MMC sub-module in a single converter and a GTFPGA card should be used, but it is not necessarily to establish a complicated multi-terminal DC network.

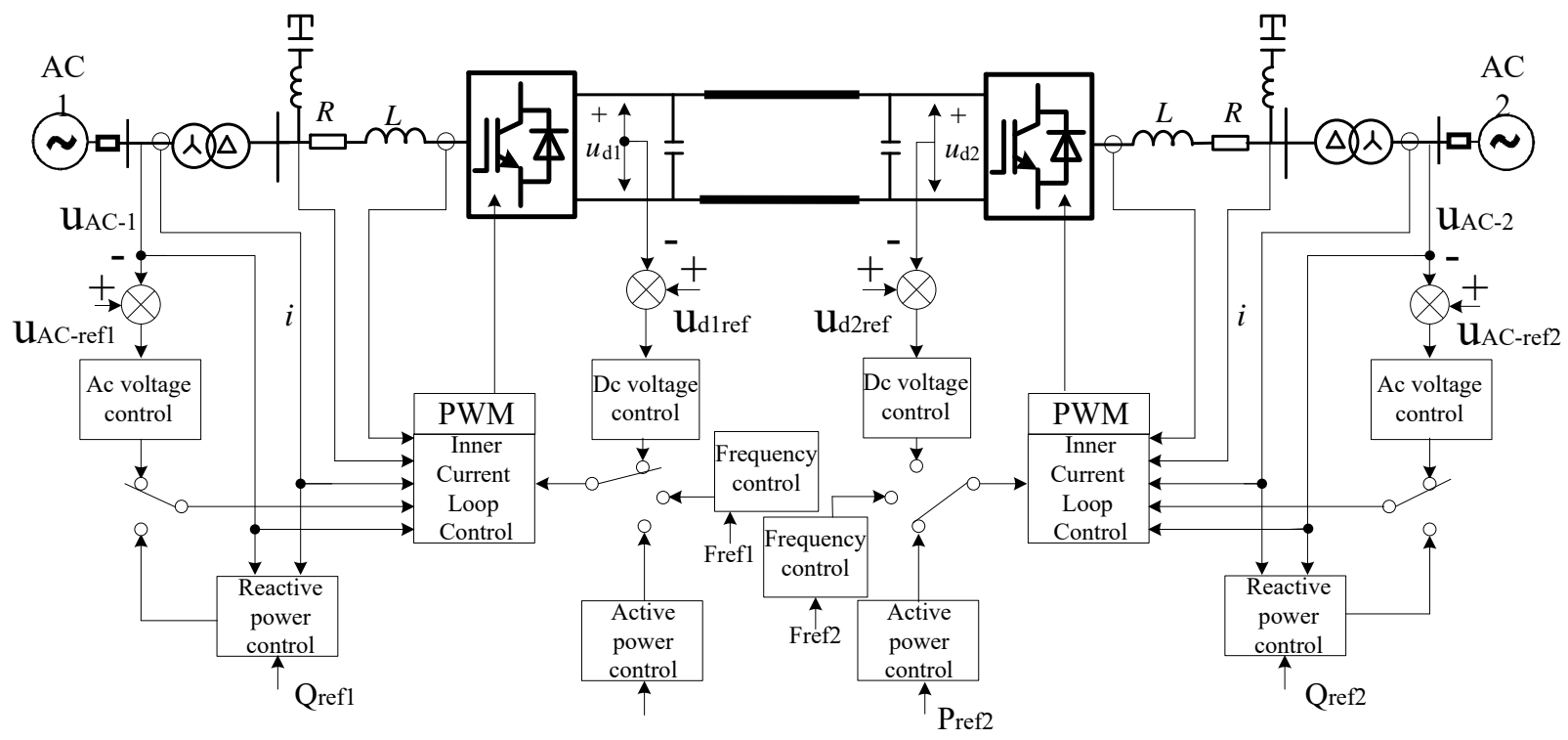

Figure 4 Layered Structure of Flexible System Control

In the system-level control, an MMC converter is equivalent to a power generator. The systemlevel control sends out control instructions for active power, reactive power, frequency, DC voltage and $\mathrm{AC}$ voltage according to the operation conditions of the system. In a DC network which is comprised of multiple MMC converter stations, the most typical operation mode is to take one station as Node $\mathrm{V}$ and the other stations as Node P. Because it is a DC network without Q or $\theta$, the $\mathrm{Q}$ adjustment of the converter stations is only for its $\mathrm{AC}$ side and has no effect on the DC side. The study of the system-level control has not carried out so far.

According to the vector decomposition control that is most used, the control system includes four links: reference quantity calculation, control external loop, control internal loop and level calculation output. The reference quantity calculation is to calculate the electrical quantity required for control rings; the external ring includes phase-locked loop, active/DC voltage control and reactive control; the internal ring includes internal ring current control and circulating current restraint control; and level calculation output provides the number of output levels for the NLM in trigger-level control. The control system of the MMC converter of each pole is identical without positive pole and negative pole distinguished and without Zhangbei Converter Station and Beijing distinguished. 


\section{Conclusions}

Under normal operation mode, each station operates at full power and the AC line only transmits a small amount of charging power. For the summary of simulation results, see Table 5.17 of 34 operation modes need to make changes to the control mode of the flexible DC converter station under normal operation mode. The main reasons are: (1) All converters operate at full load. When the converter at the receiving end is interlocked, power imbalance will occur. As a voltage control point, the converter itself operates in the state which the receiving power is at full load; therefore, it is impossible to compensate the lack of power at the receiving end due to the interlock of the converter at the receiving end, and power must be adjusted at the sending end. (2). The converter operates normally, but the DC line is overloaded. (3). The lack of the voltage control point occurs after the interlock of the converter. (4). The lack of the grounded neutral occurs after the interlock of the converter.

Therefore, the control measures to be taken are: (1) The power transmitted by the DC network reduces due to the interlock of the converter, and power is transmitted by the AC network. (2) Although the converter is not interlocked, the power of the converter needs to be reduced actively via DC control, and power is transmitted by the AC network. (3). The control point of the DC system voltage changes. (4). The ground point of the converter changes. The difference between (1) and (2): In (1), the reduction of power transmitted by the DC network is caused by the interlock of the converter and it is not necessary for the control system to make response; although the converter is not interlocked in (2), the control system must make response due to the change of the DC network structure, and otherwise, the current in the DC line will be more than $3 \mathrm{kA}$ (the maximum current permitted by an DC circuit breaker).

Table 5 Summary of Operation Modes and Simulation Results

\begin{tabular}{|c|c|c|}
\hline $\begin{array}{c}\text { Operation } \\
\text { mode } \\
\text { number }\end{array}$ & Simulation result & Response method of control system \\
\hline 4,5 & $\begin{array}{l}\text { Monopole DC voltage } \\
\text { instability }\end{array}$ & Change the voltage control point to Fengning Station. \\
\hline 8,9 & $\begin{array}{l}\text { Monopole DC voltage } \\
\text { instability }\end{array}$ & $\begin{array}{l}\text { The positive (negative) output power reduced totally at } \\
\text { Kangbao and Zhangbei is } 750 \mathrm{MW} \text {. }\end{array}$ \\
\hline 12 & $\begin{array}{l}\text { Double pole DC voltage } \\
\text { instability }\end{array}$ & $\begin{array}{l}\text { The double pole output power reduced totally at Kangbao and } \\
\text { Zhangbei is } 750 \mathrm{MW} \text {. }\end{array}$ \\
\hline 13 & $\begin{array}{l}\text { Double pole DC voltage } \\
\text { instability }\end{array}$ & $\begin{array}{l}\text { Change the voltage control point and the ground point to } \\
\text { Fengning Station. }\end{array}$ \\
\hline 14,15 & $\begin{array}{l}\text { Kangbao-Fengning Line } \\
\text { overcurrent }\end{array}$ & $\begin{array}{l}\text { The positive (negative) output power reduced totally at } \\
\text { Kangbao and Zhangbei is } 750 \mathrm{MW} \text {. }\end{array}$ \\
\hline 18,19 & $\begin{array}{l}\text { Zhangbei-Beijing Line } \\
\text { overcurrent }\end{array}$ & $\begin{array}{l}\text { The positive (negative) output power reduced totally at } \\
\text { Kangbao and Zhangbei is } 750 \mathrm{MW} \text {. }\end{array}$ \\
\hline 22 & $\begin{array}{l}\text { Kangbao-Fengning Line } \\
\text { overcurrent }\end{array}$ & $\begin{array}{c}\text { The double pole output power reduced totally at Kangbao and } \\
\text { Zhangbei is } 750 \mathrm{MW} \text {. }\end{array}$ \\
\hline 24 & $\begin{array}{l}\text { Zhangbei-Beijing Line } \\
\text { overcurrent }\end{array}$ & $\begin{array}{l}\text { The double pole output power reduced totally at Kangbao and } \\
\text { Zhangbei is } 750 \mathrm{MW} \text {. }\end{array}$ \\
\hline 26 & $\begin{array}{l}\text { Double pole DC voltage } \\
\text { instability }\end{array}$ & $\begin{array}{c}\text { Change the voltage control point and the ground point to } \\
\text { Fengning Station. }\end{array}$ \\
\hline 31,32 & $\begin{array}{l}\text { Monopole DC voltage } \\
\text { instability }\end{array}$ & $\begin{array}{l}\text { The positive (negative) output power reduced totally at } \\
\text { Kangbao and Zhangbei is } 750 \mathrm{MW} \text {. }\end{array}$ \\
\hline 33,34 & $\begin{array}{l}\text { Monopole DC voltage } \\
\text { instability }\end{array}$ & Change the voltage control point to Fengning Station. \\
\hline
\end{tabular}


The change of voltage control point and the reduction of converter output power can be done rapidly, but the change of the system ground point needs operation of the grounded knife switch at the neutral point at the DC side. Therefore, for the $17 \mathrm{~N}-1$ failures in the table above, 15 of them can be automatically completed based on the flexible DC protection system; two (The double pole at Beijing Station interlock and the double channel at the exit of Beijing Station cutoff) may lead to complete shutdown of the DC network and are restarted and operate with the neutral point at Zhangbei Station grounded.

\section{References}

[1] Gemmell B, Dorn J, Retzmann D, et al. Prospects of multilevel VSC technologies for power transmission[C]//IEEE/PES Transmission and Distribution Conference and Exposition, Chicago, 2008: 87-93.

[2] Marquardt R, Lesnicar A, Hildinger J. Modulares stromrichterkonzept für netzkupplungsanwendung bei hohen spannungen [C]//ETG-Fachtagung 2002, Bad, Nauheim, Germany: ETG, 2002: 1-7.

[3] Kong Ming, Qiu Yufeng, He Zhiyuan. Pre-charging control strategies of modular multilevel converter for VSC-HVDC[J]. Power System Technology, 2011, 35(11): 67-73(in Chinese) .

[4] Marquardt R, Lesnicar A. New concept for high voltage-modular multilevel converter[C]//Proceedings of the 35 th IEEE Annual Power Electronics Specialists Conference, 2004, Aachen, Germany: IEEE, 2004: 3831-3835.

[5] Westerweller T, Friedrich K, Armonies U, et al. Trans bay cable: world's first HVDC system using multilevel voltage-sourced converter [C]//2010 CIGRE Session, Paris, France: CIGRE, 2010, B4-101: 1-6.

[6] Magg T G, Manchen M, Krige E, et al. Caprivi link HVDC interconnector: comparison between energized system testing and real-time simulator testing[C]//2012 CIGRE Session, Paris, France: CIGRE, 2012, B4-107: 116.

[7] Wen Jun, Zhang Yigong, Han Minxiao, et al. HVDC based on voltage source converter: a new generation of HVDC technique[J]. Power system Technology, 2003, 27(1): 47-51(in Chinese).

[8] Hu Hanghai, Li Jingru, Yang Weihong, et al. The development and prospet of HVDC flexible technology[J] . Electric Power Construction, 2011, 32(5): 62-66(in Chinese).

[9] Jacobson D A N, Wang P, Karawita C, et al. Planning the next nelson river HVDC development phase considering LCC vs. VSC technology[C]//2012 CIGRE Session, Paris, France: CIGRE, 2012, B4-103: 1-12. 